\title{
WYCHOWAWCZA ROLA PRACY W KONCEPCJACH FILOZOFÓW CHRZEŚCIJAŃSKICH: STEFANA WYSZYŃSKIEGO, KAROLA WOJTYŁY I JÓZEFA TISCHNERA
}

DOI: http://dx.doi.org/10.12775/SPLP.2021.020

\section{Streszczenie}

W artykule przedstawiam wychowawczy wymiar pracy na przykładzie twórczości trzech polskich filozofów chrześcijańskich - kardynała Stefana Wyszyńskiego, Karola Wojtyły (późniejszego papieża Jana Pawła II) i Józefa Tischnera. Każdy z nich uwypuklał rolę pracy, jako czynnika determinującego wychowanie, ale też każdy przedstawiał pracę i związany z nią system wychowania $\mathrm{z}$ innej perspektywy. Wszystkie te punkty widzenia ogniskowały się jednak na człowieku postrzeganym przez pryzmat Bożego stworzenia. Człowieka, dla którego praca stała w rzędzie cnót, podobnie jak lenistwo w rzędzie grzechów. W tekście udowadniam, że wychowawcza funkcja pracy, postrzegana w kontekście cnót, u kardynała Wyszyńskiego przedstawiana była w optyce miłości, u Jana Pawła II w przestrzeni wiary, zaś Józef Tischner głosił ją z przesłaniem nadziei.

Słowa kluczowe: praca, wychowanie, nadzieja, miłość, wiara 


\title{
"YOU ALSO GO AND WORK IN MY VINEYARD..." EDUCATIONAL ROLE OF WORK ACCORDING TO CHRISTIAN PHILOSOPHERS: STEFAN WYSZYNSKI, KAROL WOJTYLA AND JOZEF TISCHNER
}

\begin{abstract}
In this article I present the educational dimension of work on the example of three Christian philosophers - Cardinal Stefan Wyszyński, Karol Wojtyła (later Pope John Paul II) and Józef Tischner. Each of them emphasized the role of work as a factor determining upbringing, but also each of them presented work and the system of upbringing connected with it from a different perspective. All these points of view, however, focused on man perceived through the prism of God's creation. Man, for whom work stood in the row of virtues, just as laziness stood in the row of sins. In the text I prove that the educational function of work, seen in the context of virtues, for Cardinal Wyszyński it was presented in the optic of love, for John Paul II in the space of faith, while Joseph Tischner preached it with a message of hope.
\end{abstract}

Keywords: work, upbringing, education, hope, love, faith

„Idźcie i wy do mojej winnicy, a co będzie słuszne, dam wam". Mt 20,4

Wśród wielu płaszczyzn, na których realizuje się nasze człowieczeństwo, jedną z najważniejszych jest praca. Doświadczenie pracy jest bowiem czymś charakterystycznym tylko dla człowieka. Jest tym czynnikiem, który wyróżnia go od reszty stworzenia ${ }^{1}$, a który leży u fundamentów kultury i dalej - cywilizacji. Oczywistą zatem wydaje się wychowawcza rola pracy, jako czynnika kształtującego, która od lat stanowi ważny element humanizmu. Praca jest podstawową powinnością moralną człowieka i wynika ona ze świadomie podjętego przez niego powołania. W niej i przez nią człowiek się realizuje. I wreszcie jej zawdzięcza swój rozwój. Magdalena Łuka, pisząc o roli pracy w życiu człowieka, przedstawia jej niepodważalne własności: „Efekty pracy człowieka są istotnym czynnikiem jego oceniania. Dzięki pracy pozyskuje środki utrzymania dla siebie i rodziny, przez nią rozwija się i dojrzewa. Praca jest fundamentem życia społecznego, stwarza i umacnia więzi społeczne, bogaci społeczeństwo, współtworzy dzieła kultury

\footnotetext{
1 Por. H. Skorowski, Humanistyczny wymiar pracy w perspektywie nauczania Kościoła katolickiego,
} „Horyzonty Wychowania”, 2015, s. 113. 
i cywilizacji, z których korzystają następne pokolenia. Brak pracy jest nie tylko źródłem kłopotów finansowych i frustracji, ale także poważnym problemem społecznym"2. Właśnie ów kontekst społeczny wychowania poprzez pracę wydaje się niezwykle istotny w obliczu oczekiwań, jakie przez to zagadnienie są człowiekowi stawiane.

W swoim artykule chciałbym przedstawić wychowawczy wymiar pracy na przykładzie trzech prezbiterów - kardynała Stefana Wyszyńskiego, Karola Wojtyły - późniejszego papieża Jana Pawła II i księdza profesora Józefa Tischnera. Wszyscy oni prócz czynności kapłańskich, w trakcie których, w głoszonych homiliach czy rekolekcyjnych konferencjach, promowali pracę jako aktywność wychowawczą, prowadzili również działalność akademicką, naukowo-dydaktyczną, przez co sami byli nauczycielami i wychowawcami rzeszy studentów. Każdy z nich uwypuklał rolę pracy, jako czynnika determinującego wychowanie, ale też każdy przedstawiał pracę i związany z nią system wychowania z innej perspektywy. Wszystkie te punkty widzenia ogniskowały się jednak na człowieku postrzeganym przez pryzmat Bożego stworzenia ${ }^{3}$. Człowieka, dla którego praca stała w rzędzie cnót, podobnie jak lenistwo w rzędzie grzechów (i to głównych) ${ }^{4}$. Postaram się udowodnić zatem, że wychowawcza funkcja pracy, postrzegana w kontekście cnót, u kardynała Wyszyńskiego przedstawiana była w optyce miłości, u Jana Pawła II w przestrzeni wiary, Józef Tischner głosił ją z przesłaniem nadziei.

Próżno w katolickiej nauce społecznej szukać jednoznacznej, lapidarnej definicji wychowania poprzez pracę. Nie oznacza to jednak, że takowa tam nie występuje. Jest ona doskonale przedstawiona jako oczywistość i postrzegana głównie przez jej społeczny wymiar. Czym bowiem, jeśli nie opisem wychowawczej funkcji pracy są następujące fragmenty z Kompendium Nauki Społecznej Kościoła: „Każde bowiem prawdziwe wychowanie powinno zmierzać do kształtowania osoby ludzkiej, mając na uwadze jej cel ostateczny i jednocześnie dobro społeczeństw, których członkiem jest człowiek i w których obowiązkach będzie on uczestniczył, gdy dorośnie”. I dalej: „Wkład, jaki rodzina może wnieść w rzeczywistość pracy, jest bardzo cenny i z wielu względów niezastąpiony. Chodzi o wkład wyrażający się zarówno w wymiarze ekonomicznym, jak też w wielkich pokładach solidarności, które posiada rodzina. Stanowią one ważne wsparcie dla tych, którzy w rodzinie znajdują się bez pracy albo poszukują zatrudnienia. Przede wszystkim i w ujęciu bardziej radykalnym - jest to wkład, który urzeczywistnia się przez

2 M. Łuka, Wychowawcze znaczenie pracy jako istota pedagogiki pracy, „Pedagogika Katolicka”, 2010, nr 2, s. 148.

3 Jak pisze kardynał Stefan Wyszyński: „Świat stworzony staje się dla nas żywym przykładem, pouczeniem i wychowawcą. Sam wygląd stworzeń oddziaływa wychowawczo, bo podziwiamy w nich doskonałość, skończoność działania Bożego". S. Wyszyński, Duch pracy ludzkiej, Poznań 1957, s. 56

4 Patrz szerzej S. Wyszyński, Duch, dz. cyt., s. 13. 
wychowanie do sensu pracy, do odkrywania jej znaczenia i przez propozycję ukierunkowania oraz wsparcia przy podejmowaniu wyboru zawodu"s. Bez wątpienia wychowanie jawi się tu jako pierwsze i podstawowe narzędzie sprzyjające pełnemu włączaniu się ludzi w życie społeczne, bo tylko w tym wymiarze, w wymiarze społecznym, jak uczy Kościół, praca ma sens. Od zarania chrześcijaństwa w doktrynie znajdujemy bowiem pochwałę wspólnotowości (Dz 2,44; Dz 4, 32-35;), która na stałe zagościła w myśli pedagogicznej niemal na całym świece. Gdzie wychowanie ,przez pracę i do pracy polega na tym, że dziecko w sposób planowy i zorganizowany ćwiczy się w celowej działalności, wytwarzając przedmioty pożyteczne dla ludzkości, tj. mające wartość użytkową. Wychowanie przez pracę i do pracy ,jest wychowaniem władcy przyrody" ${ }^{\prime}$ - w myśl posłannictwa czyńcie sobie ziemię poddaną (Rdz 1,26-28). Z drugiej zaś strony, współcześnie dostrzegamy coś zupełnie przeciwnego. Postępujący indywidualizm przejawiający się coraz częściej w egoizmie pracy wskazuje, że zagadnienie to wymaga $z$ jednej strony ponownego przemyślenia, a z drugiej umocnienia w mentalności narodu. W przedmiotowej literaturze, prócz pochwały wychowania przez pracę, znajdujemy już przecież pytania o jego aktualność i zasadność. Iwona Mandrzejewska-Smól podkreśla, iż: „Pojawiają się również tezy, że kategoria ta po roku 1989 zmieniła swój charakter, i że jest odbierana jako swoisty instrument służący celom moralnoideowym i uspołecznianiu uczniów, dlatego też większy nacisk powinien być zwrócony na edukację przez pracę, która daje możliwości nie tyle adaptacyjne wychowania przez pracę, ale emancypacyjną edukację"7. Współcześnie promowane definicje skupiają się bowiem na zindywidualizowanej funkcji wychowania. Głoszą, że: „Wychowanie przez pracę definiowane jest również jako zamierzony i celowo zorganizowany rodzaj działalności wychowawczej, którego cechę szczególną stanowi wykorzystywanie pracy w procesach oddziaływania na jednostkę i dokonywania zmian w jej osobowości"8.

Z pewnością odpowiedzią na ów kryzys zawężania postrzegania wychowawczej wartości pracy w kontekście społecznym może być poszukiwanie jej wzorców u osób, które w opinii refleksyjnej części społeczeństwa, w polskiej rzeczywistości, bez wątpienia noszą miano autorytetów. Takimi bez wątpienia są wybitni intelektualiści, a równocześnie ludzie pracy i społecznego, bezinteresownego zaangażowania - wspomniani już księża Wyszyński, Wojtyła i Tischner.

5 https://www.vatican.va/roman_curia/pontifical_councils/justpeace/documents/rc_pc_justpeace_ doc_20060526_compendio-dott-soc_pl.html (1.10.2021).

6 Tak pojmował wychowanie przez pracę Paweł Błoński. Patrz szerzej: M. Łuka, dz. cyt., s. 153.

7 I. Mandrzejewska-Smól, Wychowanie przez pracę: wspólny przedmiot zainteresowań teorii wychowania i pedagogiki pracy, w: Teoria wychowania w okresie przemian, red. E. Kubiak-Szymborska, D. Zając, Bydgoszcz 2008, s. 173.

8 Z. Wiatrowski, Podstawy pedagogiki pracy, Bydgoszcz 2000, s. 134. 
Kardynał Stefan Wyszyński (1901-1981) swoją teorię wychowawczej wartości pracy zawarł głównie w książce Duch pracy ludzkiej (pierwsze wydanie: Włocławek 1946). Bez wątpienia więc, na jej powstanie rzutowały przemyślenia i obserwacje ciężkich i traumatycznych czasów II wojny światowej. Czasu, w którym cel pracy ludzkiej nie był tylko poświęcony temu by, „czynić ziemię bardziej ludzką i bliższą Boga, bardziej odpowiadającą Jego myśli"”, ale również temu, by poprzez jej owoce szerzyć zło, śmierć i zniszczenie. „W pracy naszej stajemy się coraz bardziej częścią społeczeństwa, jesteśmy coraz mniej własnością swoją. Nie jest więc obojętne, czy pracujemy i co robimy" ${ }^{10}$. To zwracanie uwagi na wartość pracy i jej owoców nie jest jednak tylko napomnieniem w znaczeniu moralno-religijnym w nawiązaniu do słów św. Pawła: „Kto nie chce pracować, niech też nie je!" $(2$ Tes 3,10$)$. W pracy dostrzegał bowiem Prymas Tysiąclecia realizację posłannictwa Boga samego. Z jednej strony Boga Ojca - nakaz, by czynić sobie ziemię poddaną (i tym samym współpracować z Nim - przy wykańczaniu dzieła stworzenia), ale z drugiej również powołanie do pracy apostolskiej przez Chrystusa - to On bowiem, jak pisze prymas, stworzył „,szkołę pracy”" rej poprzez pracę i w pracy uczył miłości do bliźniego: „Nowa pobudka pracy! Ona to wyprowadza człowieka z ciasnego podwórka jego wyłącznie spraw na szerokie drogi miłości. Czujemy w niej, że stajemy się w pracy rodziną Bożą. Wiemy doskonale, że im wydajniejsza będzie nasza praca, tym więcej Opatrzność pozyska środków do obdzielenia ubogich i potrzebujących" ${ }^{\prime 2}$. I dalej, w podrozdziale Miłość u podstaw pracy $i$ własności napisał: „Zyskujemy nowy bodziec działania, dzięki któremu pogłębia się nasz cel pracy. Z pracy rąk naszych żyć mają bliźni. Owoce naszej pracy służą i otoczeniu naszemu"13. Nie tylko jednak innym służyć ma ludzka praca. Człowiek nie pracuje jedynie po to, by wspierać potrzebujących - karmić głodnych, dawać jałmużnę. Wychowawcza rola pracy przekłada się według Wyszyńskiego także, a może przede wszystkim, na owoce, które służą samemu pracownikowi. Oczywiście, jeśli praca, a wraz z nią trud i znój

9 S. Wyszyński, Duch, dz. cyt., s. 12.

10 Tamże, s. 13.

11 Ciekawie o tym pisze również Stefan Wyszyński w książce Źródta odrodzenia. Wspomina w niej bowiem, że Chrystusowi potrzebna jest nasza praca i nasze zaangażowanie. „Jesteśmy więc potrzebni Chrystusowi. Potrzebny jest Mu nasz rozum. Bo jakkolwiek Chrystus wszystko opowiedział, co od Ojca przyniósł, to jednakże my wiemy, że praca umysłu ludzkiego, ten nieustanny wysiłek, nawet w dziedzinie wiary, ta fides quarens intellectum sprawia, że coraz lepiej rozumiemy Słowo, które Ciałem się stało. I praca teologii odsłania przed oczyma ludzkimi coraz pełniej potęgę i wspaniałość Chrystusa. Chrystusowi są potrzebni ci wszyscy myśliciele, ci teologowie, bo On już nie mówi, On tylko miłuje. Potrzebni Mu są ci wszyscy ludzie, ci kaznodzieje, filozofowie, mówcy, pisarze, którzy nieustannie rozszerzają Chrystusa, nieustannie sprawiają, że się Go coraz lepiej rozumie". Tenże, Źródła odrodzenia, Warszawa 1993, s. 59.

12 Tenże, Duch, dz. cyt., s. 43.

13 Tamże, s. 48. 
ofiarowane są Bogu. Jak twierdzi: „Praca jest rozwijaniem w sobie miłości, kształceniem, wspaniałą sposobnością do wypowiedzenia Bogu naszej miłości ku Niemu" ${ }^{14}$. Poprzez zaangażowanie, wysiłek, cierpliwe znoszenie oporu materii, jakie na skutek nieposłuszeństwa Bogu w ogrodzie Eden stały się udziałem każdego potomka Adama, człowiek ma szanse częściowo odkupić swe winy. Odkupuje je płacąc miłością za miłość Boga. „Praca dla miłości Boga jest uczestnictwem człowieka nie tylko w dziele stworzenia, ale i dziele odkupienia naszego" ${ }^{\prime \prime}$, i dalej: „Pamiętać należy wreszcie o tym, że tylko praca z miłości ku Bogu podejmowana jest zasługująca i zbawcza”"16 i wreszcie wprost: „Praca bez miłości nie zdoła odkupić z win człowieka"17. Prymas Wyszyński uwiarygadnia tu i przedstawia rzeczywisty kontekst słów świętego Pawła, który podważa sens i zasadność wszelkiego ludzkiego trudu, jeśli pozbawiony on jest miłości. Bo przecież, jak pisze Apostoł, nawet: ,gdybym rozdał na jałmużnę całą majętność moją, a ciało wystawił na spalenie, lecz miłości bym nie miał, nic bym nie zyskał" (1 Kor 13,3). Podobnie i z pracą. Kardynał zauważa, że można czynić małe rzeczy i przez wykonywanie ich z miłością podobać się Bogu, a można też czynić rzeczy wielkie na własną zgubę.

Jeszcze jedna, ważna kwestia, którą w kontekście pracy poruszał prymas Wyszyński, a która rzutuje na całą jego twórczość, to prawa: do wykonywania pracy, do wolności pracy i prawo wyboru zawodu. Wydawać się może, że skoro człowiek, jako z natury istota społeczna ${ }^{18}$, zdaje sobie sprawę z własnej roli w państwie czy narodzie, to jednak często zdarza się, że wspólnota nie dostrzega swoistego powołania jednostki do danej pracy i stara się dowolnie, to jest według własnego uznania, dysponować osobą ludzką w tym zakresie. Kardynał mówi wprost, iż: „Może być ktoś powołany do danej pracy, ale musi mieć subiektywne usposobienie umożliwiające podjęcie tego a nie innego rodzaju pracy. I w tym subiektywnym usposobieniu człowiek jest rzeczywiście wolny - nie można go tego pozbawić19", I konkluduje tym samym, że wszystkie rodzaje przymusowej czy obowiązkowej pracy są zazwyczaj gwałtem przeciwko naturze człowieka i występkiem przeciwko prawom człowieka. Braku poszanowania podstawowych, niezbywalnych i najbardziej osobistych praw osoby ludzkiej nie można jednak tłumaczyć czym innym, niż tylko brakiem miłości. Zaś brak miłości, to nic innego, jak brak współpracy z Bogiem. Wszak wszystko, co żyje, jest z Nim poprzez pracę związane. „Warto

14 Tamże, s. 65

15 Tamże, s. 70.

16 Tamże, s. 71.

17 Tamże.

18 „Człowiek jest z natury istotą społeczną, ale niekiedy może sobie nie uświadamiać wszystkich obowiązków społecznych, i to wymaga wychowania". Tenże, Idacym w przyszłość, Warszawa 1993, s. 26.

19 Tamże, s. 49. 
mieć stale ten obraz przed oczyma, by nie przeceniać owoców własnej pracy. Człowiek bowiem nic nie tworzy, tylko przetwarza gotowe dary Boże"20.

Karol Wojtyła (1920-2005) - papież Jan Paweł II najpełniej swoją wizję wychowania poprzez pracę oddał w encyklice Laborem Exercens ${ }^{21}$ (1981 r.). W niej zawarł znamienne słowa, wskazujące na społeczny charakter pracy i określając jego wymiary od antropologicznego po etyczny: „Problem pracy należał od początku do nauczania Kościoła, jego nauki o człowieku, o życiu społecznym, a w szczególności nauki o moralności społecznej, którą wypracował wedle potrzeb różnych epok”22. Bez wątpienia, choć mówi Wojtyła i o „Kościele” i o „społeczeństwie", w jego myśli traktować można oba pojęcia jako synonim. Czymże bowiem jest Kościół w nauczaniu Papieża, jeśli nie społecznością ludu Bożego. W przekonaniu Ojca Świętego jednostka w owej wspólnocie interpretuje człowieka (osobę) i jego działalność (czyn) w kontekście wiary. Takie też jest u niego spojrzenie na pracę i wychowanie człowieka przez pracę. Pisze o tym w następujących słowach: „Kościół jednak czerpie to swoje przekonanie przede wszystkim z objawionego Słowa Bożego i dlatego to, co jest przeświadczeniem rozumu nabiera równocześnie charakteru przekonania wiary. Kościół bowiem - to warto zauważyć już tutaj - wierzy w człowieka: nie tylko w świetle doświadczenia historycznego, nie tylko przy pomocy wielorakich metod poznania naukowego myśli o człowieku i odnosi się do niego - ale myśli o nim przede wszystkim w świetle objawionego Słowa Boga Żywego, a odnosząc się do człowieka, stara się być wyrazicielem tych odwiecznych zamierzeń i tych transcendentnych przeznaczeń, jakie z człowiekiem związał ten Żywy Bóg: Stwórca i Odkupiciel"23. Wychowawcza rola pracy objawia się według Wojtyły w uczestnictwie. I to uczestnictwie dwojakiego rodzaju. Jak twierdził, każdy człowiek nie tylko bytuje i działa wśród innych, ale także bytuje i działa „wspólnie z innymi”. To zaś poprzez różne zależności i relacje ma charakter kształtujący dla każdego człowieka ${ }^{24}$. Pisał, że w relacji pracy jest to proces w gruncie rzeczy, mimo że dotyczący osoby, to jednak i ponadjednostkowy: „Ów proces zaś jest równocześnie uniwersalny: obejmuje wszystkich ludzi, każde pokolenie, każdy etap rozwoju ekonomicznego i kulturalnego, a jednocześnie jest to proces przebiegający w każdym człowieku, w każdym świadomym ludzkim podmiocie" 25 . I chociaż doskonale zdawał sobie sprawę, że kwestie

20 S. Wyszyński, Duch, dz. cyt., s. 19.

${ }^{21}$ Kwestię pracy ludzkiej porusza Karol Wojtyła również w innych encyklikach społecznych oraz w okazjonalnych przemówieniach, które podczas swojego pontyfikatu głosił. Patrz szerzej: Jerzy Gałkowski, Praca w ujęciu Karola Wojtyty, „Ethos” R. 19, nr 4 (2006), s. 174

22 Jan Paweł II, Laborem exercens, w: Encykliki Ojca Świętego Jana Pawła II, Kraków 2016, s. 93.

23 Tamże, s. 94.

24 Por. K. Wojtyła, Osoba i czyn, Lublin 2011, s. 458.

25 Jan Paweł II, dz. cyt., s. 95. 
wychowania mają swoje źródła przede wszystkim w rodzinach ${ }^{26}$, to jednak zdawał sobie sprawę, a tym samym kład nacisk na wychowanie społeczne - narodowe. $\mathrm{W}$ takim dopiero wychowaniu, w perspektywie poszanowania jednostki przez naród, a jednocześnie w oczywistej perspektywie „uznania się” człowieka jako podmiotu pracy, za element większej całości (swoistego kolektywu), który przecież przynależy do tego społeczeństwa na podstawie szczególnych więzi kultury i historii widzi Jan Paweł II sedno poruszanej problematyki. Jak zauważa: „Społeczeństwo takie - chociażby nie osiągnęło jeszcze dojrzałej formy narodu - jest nie tylko wielkim, choć pośrednim «wychowawcą» każdego człowieka (każdy wszak wychowuje się w rodzinie, na tych wartościach i wartościach, jakie składają się na całość kultury danego narodu); jest ono także wielkim historycznym i społecznym wcieleniem pracy całych pokoleń" ${ }^{27}$. Taki obraz pracy przyjąć należy zarówno kierując się rozumem jak i wiarą. $Z$ niego zaś wyrasta swoiste poczucie obowiązku pracy. Mimo, że prócz satysfakcji i dóbr materialnych niesie ona ze sobą trud, wysiłek i nierzadko niewygody, traktowana jest jako dobro, jako wartość. Rozwija się zatem w człowieku poczucie umiłowania pracy, a przez nie człowiek wspina się na wyższy poziom moralny i staje się zwyczajnie lepszym człowiekiem. Równie istotne w kontekście poruszonej etyki pracy stała się poruszona przez Wojtyłę kwestia ochrony praw pracowniczych. Jak zauważył Krzysztof Sadło: „Ważnym aspektem rozważań papieża jest uznanie prymatu osoby nad pracą oraz pracy nad kapitałem, mówiąc prościej osoby nad materią, dobra ludzkiego nad bilansem ekonomicznym"28. Innymi słowy, dopominał się poszanowania nierozerwalnie związanych z pracą „godności” oraz „praw podstawowych”.

„Nie jest zadaniem Kościoła przeprowadzanie naukowych analiz wszystkich tych zmian oraz ich możliwych następstw we współżyciu ludzi i ludów. Natomiast Kościół uznaje za swoje zadanie stałe przypominanie o godności i o prawach ludzi pracy oraz piętnowanie takich sytuacji, w których bywają one gwałcone, starając się przez to tak oddziaływać na bieg tych przemian, aby wraz z nimi dokonywał się prawdziwy postęp człowieka i społeczeństwa"29.

I w innym miejscu: „Ten na wskroś pozytywny i twórczy i wychowawczy i zasługujący charakter pracy musi stanowić podstawę również współczesnego

26 Wspomina o tym Jerzy Gałkowski: „Pierwszy krąg odpowiedzialności, powszechnie uznawany za najbardziej podstawowy, obejmuje sprawy małżeństwa i rodziny. Karol Wojtyła od początku swojej pracy duszpasterskiej i naukowej starał się szczególną troską i szacunkiem otoczyć ludzką miłość, która jest sednem i sensem małżeństwa i rodziny. Ponieważ rodzina stanowi miejsce przekazywania życia i wychowania następnych pokoleń, troska o nią jest też troską o całość wspólnoty ludzkiej. Zabieganie o dobro rodziny przyjmuje postać obowiązku pracy. Obowiązek ten spoczywa na samych małżonkach, ale i na całej wspólnocie. Rodzina też jest pierwszą szkołą pracy. J. Gałkowski, dz. cyt., s. 181.

27 Jan Paweł II, dz. cyt., s. 104.

28 https://www.idmjp2.pl/index.php/pl/2162-jan-pawel-ii-naucza-o-pracy-ludzkiej (1.10.2021).

29 Jan Paweł II, dz. cyt., s. 91. 
myślenia i wartościowania i stanowienia o niej na gruncie podmiotowych praw człowieka (...)"30.

W zadziwiający sposób w prawach człowieka krzyżują się spojrzenia na pracę kardynała Wyszyńskiego i papieża Jana Pawła II. Nie mniej zadziwiającym jest fakt, że swoją syntezę odnajdują one w myśli krakowskiego filozofa ks. profesora Józefa Tischnera (1931-2000). Wielokrotnie pisał on o pracy, o jej wymiarach i przymiotach. W jednym z najpopularniejszych tekstów poświęconych temu zagadnieniu ${ }^{31}$ właśnie zawarł następującą myśl: „Praca jest urzeczywistnieniem jakiejś nadziei. Jakiej nadziei? Czy nadziei na chleb, na przyjaźń z ludźmi, na spotkanie z Bogiem? A może chodzi o osiągnięcie pełni człowieczeństwa?" 32 . Odpowiedź nasuwa się sama - w pracy realizujemy wszystkie te nadzieje. A poprzez nadzieję realizujemy nasze człowieczeństwo. Pytając o człowieczeństwo, stawiając najwyżej w hierarchii rozważań spór o istnienie człowieka, doszukując się sensu jego funkcjonowania, działania i pracy w społeczeństwie dostrzegał Tischner rozwinięcie ludzkiego dramatu, w którym praca właśnie była na ów dramat ludzkiego życia odpowiedzią. W pracy dostrzegał realną obecność człowieka na ziemi. To w niej zauważał wspólnotę łączącą ludzi. Wspólnotę spajającą społeczeństwo wokół jednego celu - solidarnego wysiłku. Nie tylko jednak we wspólnie przeżywanej rzeczywistości (tu i teraz), ale również tej historycznej, międzypokoleniowej. Rzeczywistości, która poprzez pracę wychowywała człowieka do nadziei ${ }^{33}$, do założenia i realizacji wspólnych pragnień, celów i dążeń. Jak pisze, komentując tischnerowską filozofię pracy, Jarosław Legięć: „Człowiek ma świadomość więzi, jaka go łączy z drugim człowiekiem, wraz z którym wyprodukował przedmiot. Chociaż nie znają się osobiście, wiedzą o sobie poprzez łączność w wykonanej pracy. Człowiek nie wie, kto zbudował jego zakład pracy, ale dzięki tej osobie może dzisiaj w tym zakładzie pracować, aby żyć" ${ }^{34}$. Bez wątpienia sens pracy dostrzega Tischner w momencie, kiedy ta łączy ludzi, a nie gdy dzieli i gdy stawia między nimi bariery. „Czym jest praca? Odpowiadamy: praca jest szczególną formą rozmowy człowieka z człowiekiem, służącą podtrzymywaniu i rozwojowi ludzkiego życia" ${ }^{35}$. To w rozmowie, w dialogu właśnie następuje połączenie pracą, skupienie wokół wspólnego celu. Określa to Tischner szczególnym słowem. Tę więź nazywa braterstwem wskazując tym samym, na

30 Tamże, s. 105.

31 J. Tischner, W kręgu filozofii pracy, Kraków 1983.

32 Tamże, s. 61.

33 Wychowanie definiował Tischner głównie jako pracę wokół ludzkiej nadziei. Jak sam pisał: „Trzeba powiedzieć tak: wychowują jedynie ci, którzy mają nadzieję. Do tego należy dodać, wychowują kształtując nadzieję wychowanków. Wychowanie jest pracą około ducha - pracą według nadziei. Dopiero za nadzieją przychodzi miłość, buduje się wiara, kształtuje odpowiedni zmysł rzeczywistości”. J. Tischner, Etyka solidarności, Kraków 2005, s. 89.

34 J. Legięć, Człowiek w filozofii pracy Józefa Tischnera, Kraków 2012, s. 145.

35 J. Tischner, Etyka, dz. cyt., s. 25. 
głębię relacji wokół pracy, relacji wręcz „rodzinnej”. „Patrząc na sytuację dziś, widzimy braterstwo, jakiego nie znała nasza historia. Braterstwo ludzi pracy, braterstwo rodzone i zrodzone z matki, która jest pracą narodową. Praca staje się coraz bardziej powszechną wartością. Dzisiaj niepodległość Polski jest niepodległością polskiej pracy"36. I w innym miejscu podkreśla tę szczególną zażyłość: „Okazuje się, że praca może być rodzicielską, może być matką - matką, która rodzi braci i dlatego dzień dzisiejszy jest także dniem spojrzenia od nowej strony na tajemnicę ludzkiej pracy; jest okazją do tego, ażeby z głębi ludzkiej pracy odkryć jakiś żywioł macierzyński, żywioł ojcowski, aby zobaczyć, że człowiek rośnie z roli i soli, a także z tego co go boli" ${ }^{37}$. W słowach tych wybrzmiewają treści definiujące przyrodzony stosunek do pracy jako wartości. Lapidarnie ujął to ks. Jarosław Jagiełło pisząc o rodzajach poznania poprzez nadzieję, która pozwala człowiekowi odkryć prawdę o świecie. Nie jakimś abstrakcyjnym, lecz tym konkretnym, w którym człowiek realnie żyje, będąc powołanym do niepodległości własnej pracy. W świecie polityki i ekonomii, w którym człowiek jest z jednej strony uwikłanym w zależności (z wszechobecnym lękiem), z drugiej zaś otwartym na nadzieję z całym fenomenem (heroizmem) jej powiernictwa. W obu, podobnie jak u Wojtyły i Wyszyńskiego, praca jest sposobem poszukiwania Boga ${ }^{38}$. Boga, którego nieraz zabrakło w dążeniach ludzkiej pracy, jak chociażby w biblijnym obrazie wieży Babel, czy bliższych nam w czasie przemysłach śmierci w Auschwitz i Kołymie. Według Tischnera nie zaproszenie Boga do ludzkiej pracy skutkuje tragiczną , ,chorobą” - wyzyskiem, ten zaś najpełniej objawia się w łamaniu praw człowieka ${ }^{39}$.

Bez wątpienia zbieżność dotycząca pracy w twórczości przywołanej trójki wybitnych polskich myślicieli jest zbyt obszerna, aby zamknąć ją w ramach pojedynczego artykułu. Temat z pewnością wymaga monograficznego opracowania. Niech zatem zauważone i zaakcentowane kwestie traktowane będą jak przyczynek do szerszego opracowania, które w moim przekonaniu, z uwagi na doniosłość problematyki powinno się na polskim rynku wydawniczym wkrótce ukazać. Nie bez znaczenia pozostaje fakt, że myśl owych prezbiterów przenika się i stanowi swoistego rodzaju ciągłość. Kontynuację tę dostrzegamy głównie w dwóch nurtach myślenia. Po pierwsze, w tym konfesyjnym, gdzie swoją pełnię znajdują w przywołanych w motto poprzedzającym artykuł słowach przypowieści o robotnikach

36 Tenże, Szukajcie, Kielce, b.r.w., s. 19.

37 Tamże, s. 16.

38 Szerzej na ten temat J. Jagiełło, Józef Tischner, Kraków 2020, s. 53-65.

39 Patrz szerzej: P. Zientkowski, Idea solidarności spolecznej jako przejaw podstawowych praw człowieka w myśli Józefa Tischnera, „Paedagogia Christiana”, 1/41 (2018), 2014, s. 144-145. Więcej o prawach człowieka u Tischnera również w P. Zientkowski, Dialog jako narzędzie pedagogiki praw człowieka. Rozważania wokół koncepcji wolności według Józefa Tischnera, „Studia Pelplińskie”, t. LII, 2018, s. 451-460. 
w winnicy. Przypominają nam one oczywiście o tym, że każdy w pewnym momencie swego życia (najpóźniej w chwili śmierci) spotka Chrystusa, który zaproponuje mu życie oparte na Miłości i da tym samym szansę osiągnąć życie wieczne. Ale ta przypowieść ma i inne, równie ważne przesłanie - mówi ono o tym, że każdy człowiek jest powołany do pracy i że każda praca wychowuje. Bo cytując raz jeszcze kardynała Wyszyńskiego: „W pracy jest i wielka pokora i uległość i miłość"40. Z drugiej strony do głosu dochodzi nurt legislacyjny, przez który wszyscy trzej dopominają się poszanowania ludzkiej godności i podstawowych praw człowieka, dbając przy tym o to, by wciąż wywodzić prawo pozytywne ze źródła, jakim jest prawo Boże, nie zaś, jak forsuje modernizm: „oczekiwać, aż boskość wyłoni się z wnętrza prawa stanowionego i zamieni je w nowożytny dekalog"41.

\section{Bibliografia}

Gałkowski J., Praca w ujęciu Karola Wojtyty, „Ethos”, R. 19, nr 4 (2006).

https://www.idmjp2.pl/index.php/pl/2162-jan-pawel-ii-naucza-o-pracy-ludzkiej (1.10.2021).

https://www.vatican.va/roman_curia/pontifical_councils/justpeace/documents/ rc_pc_justpeace_doc_20060526_compendio-dott-soc_pl.html (1.10.2021).

Jagiełło J., Józef Tischner, Wyd. Naukowe Akademii Ignatianum, Kraków 2020.

Jan Paweł II, Jan Paweł II, Laborem exercens, w: Encykliki Ojca Świętego Jana Pawła II, Wyd. Rafael, Kraków 2016.

Legięć J., Człowiek w filozofii pracy Józefa Tischnera, Wyd. Księży Sercanów, Kraków 2012.

Łuka M., Wychowawcze znaczenie pracy jako istota pedagogiki pracy, „Pedagogika Katolicka” nr 2, 2010.

Mandrzejewska-Smól I., Wychowanie przez prace: wspólny przedmiot zainteresowań teorii wychowania i pedagogiki pracy, w: Teoria wychowania w okresie przemian, red. E. Kubiak-Szymborska, D. Zając, Wyd. UKW, Bydgoszcz 2008.

Skorowski H., Humanistyczny wymiar pracy $w$ perspektywie nauczania Kościoła katolickiego, „Horyzonty wychowania”, 2015, s. 113.

Tischner J., Etyka solidarności, Znak, Kraków 2005.

Tischner J., Ksiądz na manowcach, Znak, Kraków 2007.

Tischner J., Szukajcie, Wyd. Jedność, Kielce, b.r.w.

Tischner J., W kręgu filozofii pracy, Wyd. BSL, Kraków 1983.

Wiatrowski Z., Podstawy pedagogiki pracy, Wyd. Uczelniane WSP w Bydgoszczy, Bydgoszcz 2000.

\footnotetext{
40 S. Wyszyński, Duch, dz. cyt., s. 77.

${ }^{41}$ J. Tischner, Ksiądz na manowcach, Kraków 2007, s. 331.
} 
Wojtyła K., Osoba i czyn, Wyd. KUL, Lublin 2011.

Wyszyński S., Duch Ludzkiej Pracy, Wyd. Świętego Wojciecha, Poznań 1957.

Wyszyński S., Idacym w przyszłość, Warszawa 1993.

Wyszyński S., Źródła odrodzenia, Wyd. Soli Deo, Warszawa 1993.

Zientkowski P., Dialog jako narzędzie pedagogiki praw człowieka. Rozważania wokót koncepcji wolności wedtug Józefa Tischnera, „Studia Pelplińskie”, tom LII, 2018.

Zientkowski P., Idea solidarności spolecznej jako przejaw podstawowych praw człowieka w myśli Józefa Tischnera, „Paedagogia Christiana” 1/41 (2018), 2014. 